\title{
Susceptibility of targets to the vampire bat Desmodus rotundus are proportional to their abundance in Atlantic Forest fragments?
}

\author{
Marlon Zortéa ${ }^{1,2}$ (1) , Diego A. Silva² (1) \& Analice M. Calaça',2 (D)
}

1. Instituto de Ciências Biológicas, Universidade Federal de Jataí, Regional Jataí. BR 364 Km 195 Jataí, GO 75801-615, Brazil. (mzortea@uol.com.br)
2. Projeto Ecológico de Longa Duração/ PELD, Jataí, state of Goiás, Brazil.

Received 20 April 2018

Accepted 17 October 2018

Published 29 November 2018

DOI 10.1590/1678-4766e2018037

\begin{abstract}
Desmodus rotundus (É. Geoffroy, 1810) feeds preferably on mammal blood, including livestock animals, such as bovine cattle. In spite of using native preys in the wild, records of this feeding activity are scarce. In the present study, we investigated the foraging activity of $D$. rotundus based on video footage from camera traps in Atlantic Forest fragments in southern Goiás State, Brazil. Out of 23 mammal species recorded in the study area, four had interactions with Desmodus rotundus (Priodontes maximus, Tapirus terrestris, Mazama americana and Pecari tajacu). The records were obtained from early night to sunrise. There was a correlation between abundance of potential preys and the choice of the target by $D$. rotundus. Most of the bat-prey interaction occurred on the edge of fragments. The present study records for the first time the potential use of the collared peccary $(P$. tajacu) and the giant armadillo (P. maximus) in the diet of $D$. rotundus.
\end{abstract}

KEYWORDS. Chiroptera, foraging, mammals.

RESUMO. A suscetibilidade de alvos ao morcego-vampiro Desmodus rotundus é proporcional à sua abundância em fragmentos de Mata Atlântica? Desmodus rotundus (É. Geoffroy, 1810) se alimenta preferencialmente de sangue de mamíferos, incluindo animais de criação como gado bovino. Apesar de utilizarem presas nativas na natureza os registros desta atividade alimentar são escassos. Neste estudo investigamos atividade de forrageio desta espécie baseado em filmagens de armadilhas fotográficas em fragmentos de Mata Atlântica no sul de Goiás. Das 23 espécies de mamíferos registradas na área de estudo, quatro possuíram interações com Desmodus rotundus (Priodontes maximus, Tapirus terrestris, Mazama americana e Pecari tajacu). Os registros foram obtidos desde o início da noite até o crepúsculo matutino. Houve correlação entre abundância de potenciais presas e a escolha do alvo por D. rotundus. A maior parte da interação morcego-presa ocorreu na borda dos fragmentos. Este trabalho registra pela primeira vez a potencial utilização de catetos (P. tajacu) e do tatu-canastra (P. maximus) na dieta de D. rotundus.

PALAVRAS-CHAVE. Chiroptera, forrageamento, mamíferos.

The high diversity of bats around the world results from their broad food and behavioral spectrum. The diversification of feeding habits is strongly perceived in the tropical region, in particular, the Neotropics, where species that feed on fruits, leaves, seeds, nectar, arthropods, blood, and meat are found. Only three out of over 1,300 known bat species (Fenton \& Simmons, 2014) feed on blood (vampire bats). Desmodus rotundus (É. Geoffroy, 1810) is the most common species among the three vampire bat species being also responsible for rabies in herbivores, resulting in massive economic losses at the magnitude of million dollars per year (Greenhall et al., 1983; Acha \& Malaga-Alba, 1988; Belotto et al., 2005), mainly because farmers do not vaccinate cattle (JoHNSON et al., 2014).

Its diet is mainly composed of mammal blood, and it feeds secondarily on birds, and, eventually, human blood (TURNER, 1975; SCHNEIDER et al., 2001, 2009).
Despite a good documentation of bats feeding on animals, in particularly domesticated animals, such as bovine cattle (Dalquest, 1955; Voigt \& Kelm, 2006; Mialhe, 2014), the data on bat diet in natural environments using wild preys are scarce.

In the past two decades, the use of camera traps has increased exponentially, and it became an efficient tool to gather biological data on medium and large mammals (Rovero et al., 2014). The non-invasive nature of this device allows to obtain important data of behavioral aspects, evidencing interactions between species that otherwise would be difficult to obtain (DesBIEZ \& KLUYBER, 2013). Recently, the video footage of these cameras has caught the actions of vampire bats in the attempt of feeding or actually feeding on some species of wild mammals as well as domesticated animals (CAStellanos \& BANegas, 2015; Galetti et al., 2016; Gnocchi \& SRbeK-Araujo, 2017). 
In the present study, we described the feeding behavior of D. rotundus on wild mammal species in a relict area of Atlantic Forest in central Brazil. We also assessed whether the choice of the target prey was proportional to its abundance.

\section{MATERIALS AND METHODS}

The study was carried out in an area that represents the last remnant of Atlantic Forest found in the state of Goiás, comprising the municipalities of Itajá and Aporé in the southern region of the state, in mid-western Brazil (Fig. 1). Broad environmental heterogeneity and complexity characterize the region, which comprises environments of deciduous, semi-deciduous, and riparian forests within an anthropic matrix exclusively destined to livestock breeding. Data from 2016 show that about $57 \%$ of the two municipalities are composed of planted pastures, with an effective of more than 370,000 head of cattle (IMB, 2018).

We selected two fragments of semi-deciduous forests for sampling, $1 \mathrm{~km}$ apart from each other, based on satellite images and previous data collected in the region. Data collection took place from December 2015 to March 2017, when we set up five camera traps (Bushnell Trophy Cam HD model) in each fragment. The camera traps were arranged in a linear design, following the largest angle of the fragment, and were set up, whenever possible, at an average distance of approximately $1 \mathrm{~km}$ from each other. Three cameras were installed inside a fragment and two cameras on the edges. They were placed at ca. $30 \mathrm{~cm}$ from the ground and did not receive attractive baits, but were programmed to take a picture, followed by video footage of $30 \mathrm{~s}$, with 30 -s intervals between shots. We used a criterion of a period equal to or longer than one hour to consider the records of individuals of the same species independent.

In order to test whether bats interacted with species proportionally to their abundance, we made a simple linear regression between the total abundance of mammals recorded and the abundance of "target mammals." For this analysis, we considered 24 hs of mammal records and, separately, the records obtained between 17:00 and 5:00, which comprised from sunset to sunrise, when bats could be active. The moon phase was considered in this study.

\section{RESULTS}

We used an effort of 3,337 cameras/day and obtained 939 records of 23 wild mammal species. Of this total, vampire bats interacted with four species of medium and large mammals in 10 different occasions (Tab. I; Figs 2, 3), comprising only $17.3 \%$ of all the species of medium and large mammals recorded. The species in interaction recorded were the giant armadillo [Priodontes maximus (Kerr, 1792)], the lowland tapir [Tapirus terrestris (Linnaeus, 1758)], the red brocket [Mazama americana (Erxleben, 1777)], and the collared peccary [Pecari tajacu (Linnaeus, 1758)]. The records of interactions occurred at several times distributed throughout the night, from 19:00 to 05:22 (the latter outside the expected period of activity for D. rotundus and therefore not included in the regression of nocturnal mammals). Most of the records were obtained from cameras installed at the edge of the fragments. Only one record was observed inside a fragment. The camera traps recorded domestic animals, such as bovine cattle, within fragments on three occasions, but the interaction with vampire bats was observed in none. Of 10 camera trap points set up in the area, four recorded the interaction of bats with other mammals. Only one point was inside the fragment; the other three were located at a few meters from the transition edge to the pasture.

We found a significant positive correlation between the choice of the wild mammals and its abundance $\left(\mathrm{R}^{2}=\right.$ $0.266, R=0.516, p=0.011)$. The result remained significant when we selected only mammal species with nocturnal activity (from 17:01 to 5:00), a period that coincides with bat foraging $\left(R^{2}=0.363, R=0.602, p=0.002\right)$.

Considering the lunar phase, we obtained three records on the full moon day, one on the waning moon, three on the waxing moon and three on the new moon.

Tab. I. Type of interactions between vampire bats and wild mammals in Atlantic Forest fragments in southern and southeastern Goiás State, Brazil.

\begin{tabular}{|c|c|c|c|}
\hline Species & Date & Hour & Behavior \\
\hline Mazama americana & $25 / 12 / 2015$ & $00: 23$ & Flight over a potential target \\
\hline Tapirus terrestris & $19 / 05 / 2016$ & $05: 22$ & Chasing \\
\hline Pecari tajacu & $27 / 05 / 2016$ & 19:00 & Flight over a potential target \\
\hline Tapirus terrestris & $24 / 07 / 2016$ & 21:05 & $\begin{array}{l}\text { Landing on the ground, approaching the hind leg, flight, and landing on the neighbor tree. The } \\
\text { target notices and runs away }\end{array}$ \\
\hline Tapirus terrestris & $27 / 07 / 2016$ & $19: 25$ & Bat landed on the ground, sucking the hind leg of the victim. Persistent chasing on the ground \\
\hline Tapirus terrestris & $01 / 08 / 2016$ & $21: 20$ & Landing on the ground close to the hind leg \\
\hline Mazama americana & $14 / 08 / 2016$ & 02:08 & Flight and landing on a tree close to the potential target. The prey notices the presence of the bat \\
\hline Pecari tajacu & $01 / 09 / 2016$ & 23:06 & $\begin{array}{l}\text { Flight over a potential target, followed by landing on a nearby trunk. The preys notice the presence } \\
\text { of the bat }\end{array}$ \\
\hline Tapirus terrestris & $03 / 09 / 2016$ & $01: 33$ & Flight and attempt to land on the dorsum of the potential prey \\
\hline Priodontes maximus & $12 / 10 / 2016$ & $02: 45$ & Chasing \\
\hline
\end{tabular}




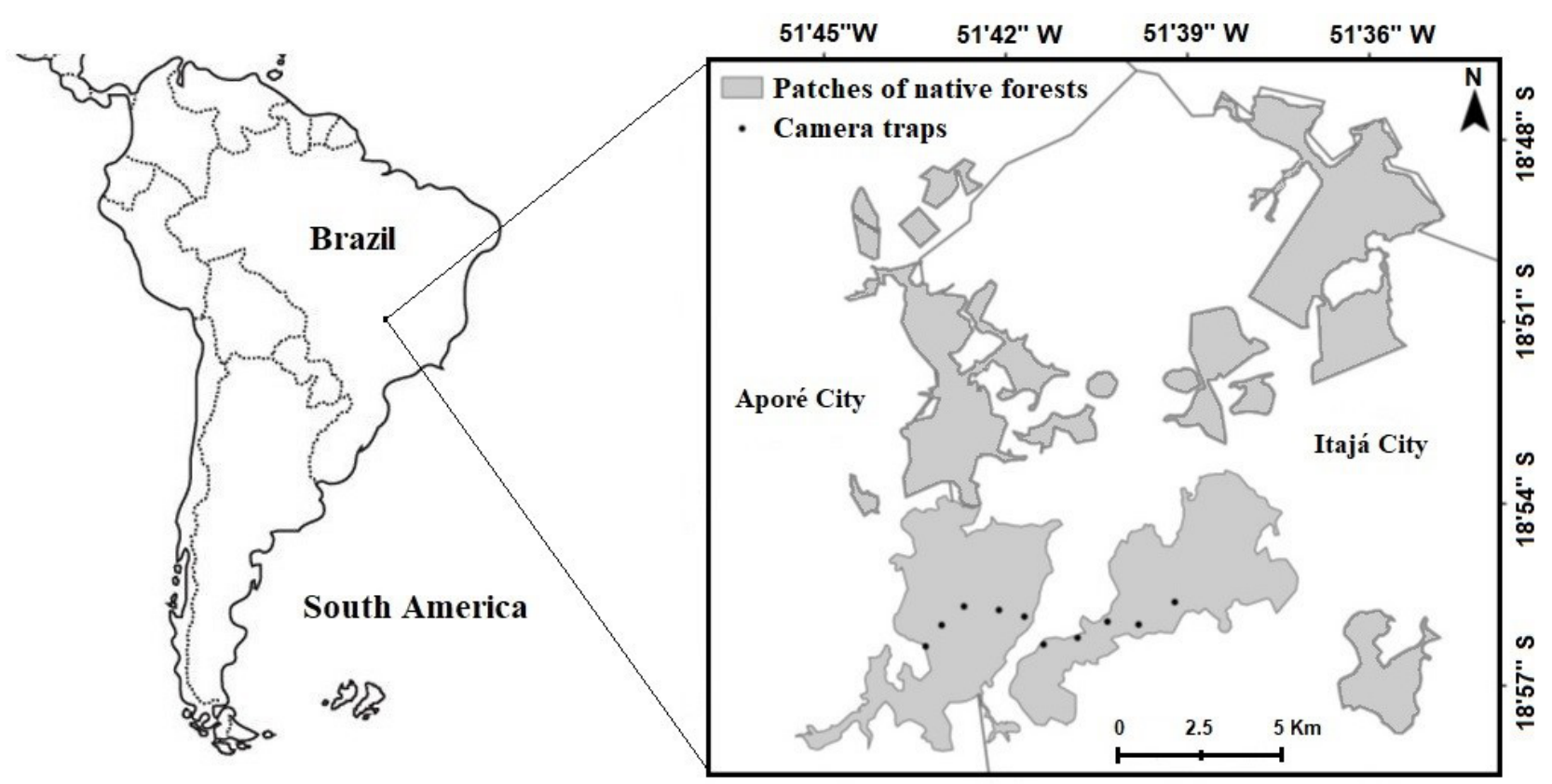

Fig. 1. Study area located in the municipalities of Itajá and Aporé, state of Goiás, Brazil. Black dots represent the sites where the camera traps were set up.
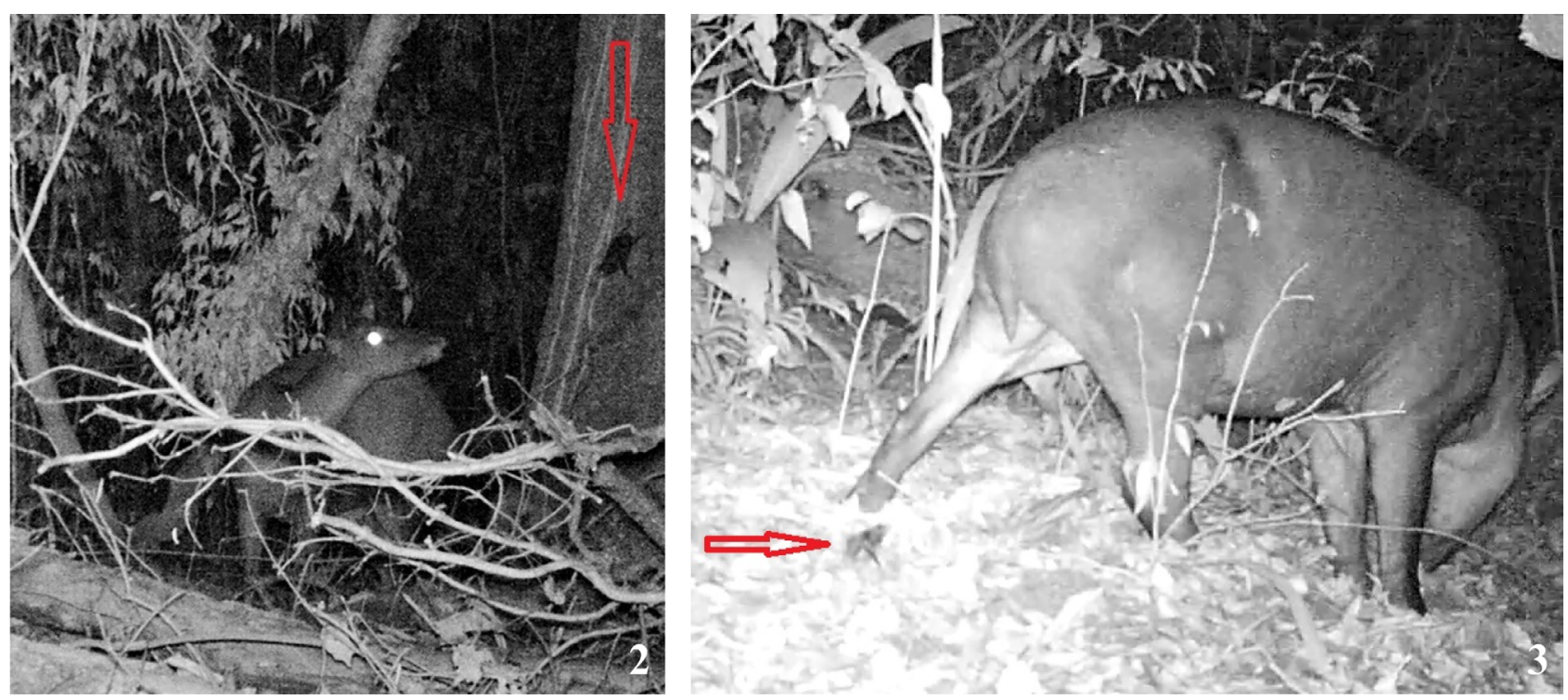

Figs 2, 3. Two records of the approach of Desmodus rotundus (É. Geoffroy, 1810): 2, a bat landing on a trunk near a deer (Mazama americana); 3, a bat on the ground very close to a tapir (Tapirus terrestris).

\section{DISCUSSION}

The diet of vampire bats comprises predominantly domestic animals, including chicken, bovine and equine cattle, and dogs, so that studies detecting the presence of wild animals are rare (COSTA \& EsBÉRARD, 2011; MIALHE, 2014; BOBROWIEC et al., 2015). BoBRowIEC et al. (2015) analyzed samples of 48 vampire bats (D. rotundus and D. youngi) in central-western Amazon using molecular data and native animal in the diet of the two species were not recorded. Likewise, VoIGT \& KeLM (2006) recorded exclusively the presence of bovine cattle in 35 bat samples analyzed through the presence of isotopes.
VoIGT \& KeLm (2006) discuss that the high abundance of domestic animals in the diet of bats results from the easiness to detect them and because they live in fenced environments, and, therefore, become more susceptible preys, due to their reduced mobility.

Records of attempts or effective foraging of vampire bats on wild mammals has increased in recent years with the use of camera traps. Camera traps recorded bat interaction with tapirs (T. terrestris), feral pigs (Sus scrofa), deer (Mazama americana and Odocoileus virginianus), and capybaras (Hydrochoerus hydrochaeris) (SÁNCHEZ-CORDERO et al., 2011; CASTELLANOS \& BANEGAS, 2015; GALETTI et al., 2016; GNOCCHI \& SRBEK-ARAujo, 2017). Of the records of 
interaction between bats and terrestrial mammals obtained in the area, only one showed effective foraging, on a tapir individual. Until now, the giant armadillo and collared peccary as target were not recorded in the literature, then it records represents the first one within the diet breadth of the vampire bats; Giant armadillo can reach over $32 \mathrm{~kg}$ and has a predominantly nocturnal habit, while collared peccary (ca. $19 \mathrm{~kg}$ ) can be active any time during the day or night (EISENBERG \& REDFORD, 1999).

The approaching methods were similar to those recorded by GNOCCHI \& SRBEK-ARAUJO (2017) in the Atlantic Forest, in which the bat lands vertically on a trunk, then on the soil, and waits for the right moment to get closer to its target. We observed that the bat chose the hind leg to feed in detriment of the dorsum, as it was described in other studies (SÁNCHEZ-CoRdero et al., 2011; CASTELlANOS \& BANEGAS, 2015; GNocChi \& SRbeK-Araujo, 2017). In the other three species, several attempts to get closer were recorded, like landing on nearby trunks, on the ground, attempts to access the dorsum of the animals, followed by flyby and chasing, but the cameras could not catch whether the attacks were succeeded because the animals did not remain within the camera angle.

As our activity records comprised several lunar phases, including the full moon, it is possible that the vampire bats have chosen the darkest hours of these days to forage to avoid predation, as preconized by FLORES-CRESPO et al. (1972). Data on time activity showed that D. rotundus is active throughout the night, which includes a record of chasing prey almost until sunrise.

We observed that interactions occurred, in particular, with large species of the mammal assemblage. Functional attributes of species, such as body size and habit, can increase their susceptibility as potential prey of vampire bats and turn them into the main food source of these bats in sites where bovine cattle does not prevail. However, this is not the case in our study area with thousands of heads of cattle. One question that arises from this study is why some vampire bats spend more energy on costly prey (native wildlife) if the region has abundant and more accessible preys (cattle)? Some studies show that in areas where domestic and wild animals are present, D. rotundus feeds exclusively on cattle and horses (Turner, 1975; Voigt \& Kelm, 2006).

Acknowledgements. The authors thank the CNPq and FAPEG in the scope of the PELD Jataí project (Process \#2012/10267 00 1108), for the logistic and financial support. AMC thanks the CNPq/FAPEG for the DTI scholarship granted during the study. Seixas R. Oliveira for the providential help in the field.

\section{REFERENCES}

Acha, P. N. \& Málaga-Alba, M. 1988. Economic losses due to Desmodus rotundus. In: GreENHALL, A. M. \& SCHIMIDT, U. eds. Natural history of vampire bats. Boca Raton, CRC Press, p. 208-213.
Belotto, A.; Leanes, L. F.; Schneider, M. C.; Tamayo, H. \& Correa, E. 2005. Overview of rabies in the Americas. Virus Research 111:5-12.

Bobrowiec, P. E. D.; Lemes, M. R. \& Gribel, R. 2015. Prey preference of the common vampire bat (Desmodus rotundus, Chiroptera) using molecular analysis. Journal of Mammalogy 96:54-63.

Castellanos, A. X. \& Banegas, G. A. 2015. Vampire bats bite lowland tapirs in Yasuni National Park, Ecuador. Tapir Conservation 24:7.

Costa, L. M. \& EsBÉRARD, C. E. L. 2011. Desmodus rotundus (Mammalia: Chiroptera) on the southern coast of Rio de Janeiro state, Brazil. Brazilian Journal of Biology 71:739-746.

DALQUEST, W. W. 1955. Natural history of the vampire bats of eastern Mexico. American Midland Naturalist 53:79-87.

Desbiez, A. L. J. \& Kluyber, D. 2013. The role of giant armadillos (Priodontes maximus) as physical ecosystem engineers. Biotropica 45:537-540.

Eisenberg, J. F. \& Redford, K. H. 1999. Mammals of the Neotropics: The central Neotropics. Vol. 3: Ecuador, Peru, Bolivia, Brazil. Chicago, University of Chicago Press. 609p.

Fenton, M. B. \& Simmons, N. B. 2014. Bats. A World of Science and Mystery. Chicago, University of Chicago Press. 240p.

Flores-Crespo, R.; Linhart, S. B.; Burns, R. J. \& Mitchell, G. C. 1972. Foraging behavior of the common vampire bat related to moon light. Journal of Mammalogy 53:366-368.

Galetti, M.; Pedrosa, F.; Keuroghlian, A. \& Sazima, I. 2016. Liquid lunch - vampire bats feed on invasive feral pigs and other ungulates. Frontiers in Ecology and the Environment 14:505-506.

Gnocchi, A. P. \& Srbek-Araujo, A. N. 2017. Common Vampire Bat (Desmodus rotundus) feeding on Lowland Tapir (Tapirus terrestris) in an Atlantic Forest remnant in southeastern Brazil. Biota Neotropica 17(3):e20170326.

Greenhall, A. M.; Joermann, G.; Schmidt, U. \& Seidel, M. R. 1983. Desmodus rotundus. Mammalian Species 202:1-6.

IMB. 2018. Perfil socioeconômico dos municípios goianos. Available at $<$ http://www.imb.go.gov.br/>. Accessed on 01 August 2018.

Johnson, N.; Aréchiga-Ceballos, N. \& Aguilar-Setien, A. 2014. Vampire bat rabies: ecology, epidemiology and control. Viruses 6:1911-1928.

Mialhe, P. J. 2014. Preferential prey selection by Desmodus rotundus (E. Geoffroy, 1810, Chiroptera, Phyllostomidae) feeding on domestic herbivores in the municipality of São Pedro - SP. Brazilian Journal of Biology 74(3):579-584.

Rovero, F.; Martin, E.; Rosa, M.; Ahumada, J. A. \& Spitale, D. 2014. Estimating Species Richness and Modelling Habitat Preferences of Tropical Forest Mammals from Camera Trap Data. Plos One 9(7):e110971.

Sánchez-Cordero, V.; Botello, F.; Magaña-Cota, G. \& Iglesias, J. 2011. Vampire bats, Desmodus rotundus, feeding on white-tailed deer, Odocoileus virginianus. Mammalia 75:91-92.

Schneider, M. C.; Aron, J.; Santos-Burgoa, C.; Uieda, W. \& Ruizvelasco, S. 2001. Common vampire bat attacks on humans in village of the Amazon region of Brazil. Cadernos de Saúde Pública 17(6):1531-1536.

Schneider, M. C.; Romijn, P. C.; Uieda, W.; Tamayo, H.; Silva, D. F.; Belotto, A.; Silva, J. B. \& Leanes, L. F. 2009. Rabies transmitted by vampire bats to humans: An emerging zoonotic disease in Latin America? Revista Panamericana de Salud Publica 25:260-269.

TURNER, D. C. 1975. The vampire bat: a field study in behaviour and ecology. Baltimore, The Johns Hopkins University Press. 145p.

Voigt, C. C. \& Kelm, D. H. 2006. Host preference of the common vampire bat (Desmodus rotundus; Chiroptera) assessed by stable isotopes. Journal of Mammalogy 87:1-6. 